\title{
Acquisition and Maintenance of Enterotoxin Plasmids in Wild-type Strains of Escherichia coli
}

\author{
By SYLVIA M. SCOTLAND,* NIGEL P. DAY AND BERNARD ROWE \\ Division of Enteric Pathogens, Central Public Health Laboratory, London NW9 5HT, U.K.
}

(Received 2 March 1983; revised 6 May 1983)

\begin{abstract}
Enterotoxigenic strains of Escherichia coli (ETEC) may produce a heat-labile enterotoxin (LT), a heat-stable enterotoxin (ST) or both enterotoxins. Certain serogroups are represented more frequently than others in ETEC isolated from humans. The transfer of three plasmids encoding enterotoxin production (Ent) to 22 non-toxigenic $E$. coli strains of many different $\mathrm{O}: \mathrm{H}$ serotypes was studied. The Ent plasmids encoded ST (TP276), or LT (TP277), or ST + LT (TP214), and all carried antibiotic-resistance determinants. Twenty-one recipient strains acquired TP214, 18 acquired TP277 and 14 acquired TP276. Strains of those serotypes to which ETEC in diarrhoeal studies commonly belong neither acquired nor maintained Ent plasmids with a higher frequency than strains of those serotypes to which ETEC rarely belong. The recipient strains, with one exception, all expressed ST, or LT, or ST and LT, when they had acquired the appropriate plasmid; a non-motile strain belonging to $\mathrm{O}$ serogroup 88 expressed LT but failed to express ST when it acquired TP214 or TP277.
\end{abstract}

\section{INTRODUCTION}

Enterotoxigenic strains of Escherichia coli (ETEC) are an important cause of diarrhoeal disease in man and animals. In a number of studies it has been noted that ETEC from humans commonly belong to a restricted range of serogroups (Cravioto et al., 1979; DeBoy et al., 1980; Merson et al., 1979; Ørskov et al., 1976). In the study of ETEC strains isolated in various countries by Cravioto et al. (1979), 108 (66\%) of 164 strains which belonged to identifiable $\mathrm{O}$ groups, belonged to serogroups $\mathrm{O} 6, \mathrm{O} 8, \mathrm{O} 63, \mathrm{O} 78$ or $\mathrm{O} 159$; an additional 41 strains $(25 \%)$ belonged to serogroups $\mathrm{O} 15, \mathrm{O} 25, \mathrm{O} 27, \mathrm{O} 114, \mathrm{O} 115, \mathrm{O} 128$ or O148. In a similar study by Ørskov et al. (1976), 101 (98\%) of 103 ETEC strains which belonged to identifiable $O$ groups belonged to serogroups $\mathrm{O} 6, \mathrm{O} 8, \mathrm{O} 15, \mathrm{O} 20, \mathrm{O} 25, \mathrm{O} 78, \mathrm{O} 115$ or $\mathrm{O} 128$. The restriction of ETEC to a small number of $\mathrm{O}$ serogroups may be of practical importance in the preliminary screening of strains for enterotoxigenicity (Merson et al., 1980). In some serogroups, for example $E$. coli O128, the enterotoxigenic strains are of many different flagellar types (Reis et al., 1980; Scotland et al., 1981). In other serogroups enterotoxigenic strains usually belong to only one flagellar type; for example O6.H16, O8.H9, O148.H28 (Back et al., 1980; DeBoy et al., 1980; Merson et al., 1979; Ørskov \& Ørskov, 1977; Smyth et al., 1979). ETEC of the same O :H serotype have been isolated in widely separated geographical areas.

ETEC isolated from humans may produce a heat-stable enterotoxin (ST), a heat-labile enterotoxin (LT), or both enterotoxins, and it has been noted that certain serotypes are usually correlated with a particular pattern of enterotoxin production. For example enterotoxigenic strains of E. coli O6. H16 usually produce ST and LT (Merson et al., 1979; Scotland et al., 1977; Smyth et al., 1979). In contrast, enterotoxigenic strains of $E$. coli $\mathrm{O} 128$ of most $\mathrm{H}$ types, including $\mathrm{H} 7, \mathrm{H} 12, \mathrm{H} 21$ and $\mathrm{H} 27$, usually produce ST, but so far only strains of $E$. coli O128. H49

Abbreviations: ETEC, enterotoxigenic strains of Escherichia coli; LT, heat-labile enterotoxin; MRHA, mannose-resistant haemagglutination; ST, heat-stable enterotoxin. 
producing LT have been reported (DeBoy et al., 1980; Merson et al., 1979; Reis et al., 1980; Scotland et al., 1981). The production of ST and LT has been shown to be plasmid mediated; enterotoxin (Ent) plasmids have been identified which code for LT only, ST only, or LT and ST (Evans et al., 1975; Gyles et al., 1974; McConnell et al., 1980, 1981; Scotland et al., 1979).

The prevalence of certain serotypes amongst ETEC, and their isolation from various parts of the world, may reflect the particular ability of such serotypes to acquire or maintain Ent plasmids. In the present investigation, 22 non-enterotoxigenic strains of $E$. coli were tested to see if they differed in their ability to acquire three enterotoxin plasmids coding for LT only, ST only or ST and LT. These Ent plasmids carried antibiotic-resistance determinants so that their transfer to and stability in the recipient strains could be studied more easily. The wild-type recipients included $E$. coli strains of serotypes to which ETEC commonly belong, such as O6.H16 and a number of different $\mathbf{H}$ types of $\mathrm{O128}$; they also included strains belonging to serogroups in which ETEC are rarely found, for example, $\mathrm{Ol}$ and $\mathrm{O} 154$.

\section{METHODS}

Donor strains of bacteria. Three strains of E. coli $\mathrm{K} 12$ carrying autotransferring plasmids coding for enterotoxin production were used; they were auxotrophic, lactose non-fermenting and streptomycin-resistant.

Strain 50R219 carried plasmid TP214 coding for ampicillin resistance and production of both ST and LT; this plasmid had been isolated from E. coli strain E2985/76 (O159.H34) (Scotland et al., 1979) and had been characterized as a derepressed F-like plasmid by McConnell et al. (1979).

Strain 52R83 carried plasmid TP277 coding for kanamycin resistance and production of LT. The LT plasmid (TP235) had been isolated from E. coli strain E5798/76 (O7. H18) (Scotland et al., 1979). It has been 'marked' with a kanamycin resistance gene from pML2 and characterized as an F-like plasmid by McConnell et al. (1980).

Strain 52R90 carried plasmid TP276 coding for tetracycline resistance and ST production. The ST plasmid (TP224) had been isolated from E. coli strain E7476/77 (O?H27) (Scotland et al., 1979); this strain has now been assigned to a new serogroup O166 (Dr F. Ørskov, personal communication). TP224 had been marked with tetracycline resistance by Dr H. R. Smith using the following procedure. The ST plasmid was transferred into $E$. coli K12 carrying the tetracycline resistance transposon Tn10 (Foster et al., 1975) on the chromosome. Enterotoxigenic transconjugants were mated with $E$. coli $\mathrm{K} 12$ selecting for tetracycline resistance and a number of resulting strains including 52R90 were analysed to show that a single plasmid coded for drug resistance and ST production.

Recipient strains of bacteria. Wild-type strains of $E$. coli isolated from human faecal specimens were examined for use as possible recipient strains in conjugation experiments. These strains had been maintained on Dorset egg agar at room temperature in the culture collection of the Division of Enteric Pathogens. They had been identified by biochemical tests and by serotyping techniques using $\mathrm{O}$ groups 1-164 and $\mathrm{H}$ antigens $1-56$. They were originally selected as being representative of serotypes in which ETEC are either commonly found or rarely found. They were then tested for colicinogeny, haemolysis, haemagglutination, drug resistance and the presence of transfer factors. These properties are often plasmid-encoded and might affect the ability of the strain to acquire an Ent plasmid, either by exclusion of the incoming plasmid or by failure of the two plasmids to co-exist in the host bacterium. So when possible, wild-type strains were chosen for further study only if they lacked the aforementioned properties. Occasionally such negative strains were not available and some of the wild-type strains studied further did possess these properties.

A number of non-toxigenic wild-type strains were of serogroups to which ETEC rarely belong. These included three strains of serogroup O1, with flagellar antigens H5, H34 or H45 from healthy infants; Taylor (1961) reported that strains of serogroup $\mathrm{Ol}$ are frequently isolated from the faeces of healthy infants. Strains of serotype O40. H3 and $\mathrm{O} 71 . \mathrm{H} 48$, studied by Klipstein et al. (1978) and $\mathrm{O} 88 . \mathrm{H}^{-}$from healthy infants were also included. Strain SC449 (E. coli O154. H4) was isolated from many healthy adults after their arrival in the Persian Gulf (Rowe, 1973); feeding experiments have shown that this strain is able to colonize the human intestine, but it has not been associated with diarrhoeal disease or toxin production (unpublished results).

Seven strains of serogroup O6 were studied as recipients. Strains of serotype O6. H16 are usually toxigenic but two non-toxigenic strains, E3483 and E1437/69, were available in our culture collection. Spontaneous nontoxigenic variants were also isolated from two $\mathrm{ST}^{+} \mathrm{LT}^{+}$strains, E219/69 and E1392 to compare their ability to acquire Ent plasmids. E219/69 and E1392 also possessed colonization factor antigen CFA/II as described by Evans \& Evans (1978). The variant from strain E219/69 lost the ability to produce ST, LT and CFA/II. Two variants were obtained from E1392; both failed to produce ST or LT, but one had retained the ability to produce $\mathrm{CFA} / \mathrm{II}$. Strains of serotype $\mathrm{O} 6 . \mathrm{H} 1$ and $\mathrm{O} 6 . \mathrm{H}^{-}$were compared as representatives of serotypes in which ETEC are rarely found; Taylor (1961) reported that strains of $E$. coli O6 are common isolates from the faeces of healthy infants. 
Table 1. Properties and sources of nalidixic acid-resistant mutants of wild-type strains of Escherichia coli

\begin{tabular}{|c|c|c|c|c|c|c|c|}
\hline $\begin{array}{c}\text { Reference no. } \\
\text { of mutant }\end{array}$ & Serotype* & $\begin{array}{l}\text { Derived from } \\
\text { wild-type } \\
\text { strain no. } \dagger\end{array}$ & $\begin{array}{c}\text { Country of } \\
\text { isolation }\end{array}$ & $\begin{array}{l}\text { Production of } \\
\text { colicin or } \\
\text { haemolysin }\end{array}$ & MRHA $\ddagger$ & $\begin{array}{l}\text { Antibiotic } \\
\text { resistance } \$\end{array}$ & $\begin{array}{l}\text { Ability to } \\
\text { mobilize } \\
\text { NTP107 }\end{array}$ \\
\hline G259 & O1.H5 & E16040 & Bangladesh & None & None & None & + \\
\hline G257 & O1. H34 & E14137 & Bangladesh & None & None & None & + \\
\hline G258 & O1.H45 & E14247 & Bangladesh & None & None & None & - \\
\hline G153 & O6. H16 & E3483 & Canada & Colicin & None & None & - \\
\hline G176 & O6.H16 & E219/69 & Sharjah & None & None & None & - \\
\hline G177 & O6. H16 & E1437/69 & Sharjah & None & None & None & - \\
\hline G337 & O6. H16 & E1392 & Hong Kong & None & Calf & $\mathrm{Sm} \mathrm{Su}$ & - \\
\hline G338 & O6.H16 & E1392 & Hong Kong & None & None & $\mathrm{Sm} \mathrm{Su}$ & - \\
\hline G178 & O6.H1 & E3998 & Britain & Haemolysin & None & None & - \\
\hline G157 & $\mathrm{O} 6 . \mathrm{H}^{-}$ & E6339 & Britain & Haemolysin & Human & None & - \\
\hline G154 & $\mathrm{O} 25 . \mathrm{H} 42$ & E9031 & Mexico & None & None & None & - \\
\hline G155 & $\mathrm{O} 25 . \mathrm{H}^{-}$ & E6655 & Brazil & None & None & None & - \\
\hline G182 & O40.H3 & E2722/1 & Britain & None & None & None & - \\
\hline G181 & O71.H48 & E2698/1 & Britain & None & None & None & - \\
\hline G158 & $\mathrm{O} 88 . \mathrm{H}^{-}$ & E8026 & Britain & None & None & None & - \\
\hline G256 & O128.H10 & E14854 & Britain & None & None & None & - \\
\hline G254 & O128.H18 & E8124 & Britain & None & None & None & - \\
\hline G255 & O128.H27 & E9055 & Costa Rica & None & None & None & - \\
\hline $\mathrm{G} 260$ & O128.H49 & E8412 & Gambia & None & None & None & - \\
\hline G334 & O154.H4 & SC449 & Sharjah & None & None & None & - \\
\hline G159 & O159.H34 & E8013 & Canada & None & None & None & - \\
\hline
\end{tabular}

${ }^{*} \mathrm{H}^{-}$, non-motile.

† Strains E1392 and E219/69 were $\mathrm{ST}^{+}$and $\mathrm{LT}^{+}$and strain E8412 was $\mathrm{LT}^{+}$when first isolated, and nontoxigenic variants were selected. All other strains were non-toxigenic.

$\ddagger$ MRHA, mannose-resistant haemagglutination of human or calf erythrocytes.

$\S \mathrm{Sm}$, streptomycin; Su, sulphathiazole.

Strains representative of serotypes to which ETEC commonly belong, in addition to $E$. coli O6. H16, included those of serotypes $\mathrm{O} 25 . \mathrm{H}^{-}, \mathrm{O} 25 . \mathrm{H} 42, \mathrm{O} 128 . \mathrm{H} 10, \mathrm{O} 128 . \mathrm{H} 18, \mathrm{O} 128 . \mathrm{H} 27$ and $\mathrm{O} 159 . \mathrm{H} 34$. The wild-type strains chosen were all non-toxigenic when received by our laboratory. All strains of serotype $\mathrm{O} 128$. H49 in our culture collection produced LT, so a spontaneous non-toxigenic variant was selected from strain E8412.

A mutant resistant to nalidixic acid $\left(50 \mu \mathrm{g} \mathrm{ml}^{-1}\right)$ was selected from each of the 21 wild-type strains for use as a recipient in transfer experiments; the characteristics of these strains are given in Table 1. For comparison, a nalidixic acid-resistant sub-strain of $E$. coli $\mathrm{K} 12$ (J53-1) was also tested as a recipient.

Characterization of recipient strains. Bacterial strains were tested for resistance to ampicillin, chloramphenicol, furazolidone, gentamicin, kanamycin, nalidixic acid, streptomycin, sulphathiazole, tetracycline and trimethoprim by the strip diffusion method or on solid media as described by Anderson \& Threlfall (1974).

Colicinogeny was detected by the agar overlay method of Fredericq (1957) using the sensitive indicator strain $E$. coli ROW.

Strains were plated on newly poured nutrient agar (Oxoid) containing horse blood $(2 \cdot 5 \%, \mathrm{v} / \mathrm{v})$ to detect haemolysin production.

Strains were tested for their ability to produce ST and LT by methods described previously (Gross et al., 1976) using the Chinese hamster ovary cell test for LT and the infant mouse test for ST. A gut/body weight ratio in the infant mouse test of greater than 0.10 was considered positive, and a ratio of less than 0.08 negative. In some experiments, filtrates were concentrated tenfold using an Amicon UM2 filter before testing for the presence of ST in the usual manner.

Strains were passaged twice on CFA agar (Evans et al., 1977a) and tested for haemagglutination of human (group A) or calf erythrocytes in the presence and absence of D-mannose $(0 \cdot 5 \%, \mathrm{w} / \mathrm{v})$. Strain G337 gave mannoseresistant haemagglutination (MRHA) of calf erythrocytes; this strain was derived from strain E1392 (E. coli O6. H16), which gave a similar haemagglutination pattern and had been shown by immunodiffusion tests to possess CFA/II. Strain G157 gave MRHA of human erythrocytes only.

Mobilization tests as described by Scotland et al. (1979) were used to detect the presence of transfer factors in the nalidixic acid-resistant recipient strains. These were carried out using the $E$. coli $\mathrm{K} 12$ substrains $38 \mathrm{R} 960$, carrying the non-autotransferring kanamycin-resistance plasmid NTP107 (McConnell et al., 1979) and 10R151 Str ${ }^{\mathrm{T}}$ as the final recipient. 
Selection and maintenance of toxigenic transconjugants. For transfer experiments, $0 \cdot 1 \mathrm{ml}$ of overnight cultures of donor and recipient strains were inoculated into $10 \mathrm{ml}$ Hedley-Wright broth and incubated $24 \mathrm{~h}$ at $37^{\circ} \mathrm{C}$ without shaking. The mating mixtures were washed twice and concentrated tenfold in 0.25 Ringers solution. Dilutions of mating mixtures were plated on DST agar (Oxoid) containing nalidixic acid $\left(50 \mu \mathrm{g} \mathrm{ml}^{-1}\right)$ for a count of total recipient bacteria, and on DST agar containing nalidixic acid and an appropriate antibiotic (ampicillin, $50 \mu \mathrm{g} \mathrm{ml}^{-1}$; kanamycin, $30 \mu \mathrm{g} \mathrm{ml}^{-1}$; tetracycline, $10 \mu \mathrm{g} \mathrm{ml}^{-1}$ ) to select transconjugants which had acquired the toxin plasmid carrying antibiotic resistance.

A single transconjugant from each selection was checked for drug resistance, toxin production and $O$ serogroup, and stored on a Dorset egg slope at room temperature. In a few experiments a number of transconjugants were examined. At 6 and 12 months at least 100 colonies were recovered from the slope culture and examined for loss of drug resistance.

The ability of some transconjugants to transfer the enterotoxin plasmid which they had acquired was tested in overnight mating experiments (see above) using the streptomycin-resistant $E$. coli $\mathrm{K} 12$ substrains 712 or $10 \mathrm{R} 151$ as recipients.

\section{RESULTS}

\section{Transfer of plasmids coding for drug resistance and toxin production}

Transfer frequencies of TP214 (ST-LT-Ap), TP277 (LT-Km) and TP276 (ST-Tc), as measured by the proportion of recipient bacteria which acquired the drug-resistance marker after $24 \mathrm{~h}$, are shown in Tables 2,3 and 4.

Table 2 shows the proportion of recipient bacteria of strains belonging to serogroup O6 which acquired drug resistance. All strains accepted TP214, with the proportion of ampicillin-resistant recipient bacteria varying from $1 \times 10^{-1}$ to $2 \times 10^{-5}$. For all strains fewer bacteria acquired either TP277 or TP276 and in some cases no transfer was detected. G337 and G338 were derived from the same wild-type strain but they differed in their ability to acquire TP214.

Transfer of the Ent plasmids to strains of other serotypes to which toxigenic strains commonly belong is shown in Table 3. One recipient strain, G154 (O25. H42), failed to acquire any of the three plasmids. Strain G254 (O128.H18) failed to acquire TP276 and acquired TP214 and TP277 at a low frequency $\left(<10^{-6}\right)$. For the other five strains a greater proportion of bacteria acquired TP214 than acquired TP277 or TP276.

Transfer of the Ent plasmids to strains belonging to serogroups to which ETEC rarely belong is shown in Table 4. Two strains, G259 (O1 . H5) and G257 (O1 . H34) failed to acquire TP276. In all other experiments, transfer of the Ent plasmids was detected, although in most cases a higher proportion of recipient bacteria acquired TP214 than acquired TP276 or TP277.

Escherichia coli K12, substrain J53-1, acquired TP214 and TP277 at a high frequency and acquired TP276 at a frequency of $9 \times 10^{-3}$, which was higher than the frequencies with which any of the wild-type strains acquired this plasmid.

Acquisition of an Ent plasmid did not result in changes in the following properties of the wildtype strains: transconjugants of G153 and G334 were still colicinogenic; transconjugants of G157 and G178 were still haemolytic; transconjugants of G337 and G338 remained resistant to streptomycin and sulfathiazole; transconjugants of G157 and G337 gave MRHA.

\section{Expression of enterotoxin genes in wild-type E. coli recipient strains}

Recipient bacteria which had acquired Ent plasmids were initially recognized by the drugresistance character with which the plasmid was marked. Such resistant transconjugants were then checked for their ability to produce enterotoxins. All resistant transconjugants from the wild-type recipients which acquired TP277 (LT-Km) were kanamycin-resistant and $\mathrm{LT}^{+}$. Similarly, with the exception of only one wild-type recipient strain, all wild-type recipients which acquired TP214 (ST-LT-Ap) were ampicillin-resistant, $\mathrm{ST}^{+}$and $\mathrm{LT}^{+}$, and those which acquired TP276 (ST-Tc) were tetracycline-resistant and ST $^{+}$. However, the recipient strain $\mathrm{G} 158\left(\mathrm{O} 88 . \mathrm{H}^{-}\right)$differed from all the others in expression of toxin production. When this strain acquired TP214 or TP276, the drug-resistant transconjugants failed to produce ST. Five ampicillin-resistant transconjugants of $\mathrm{G} 158$ from each of two separate transfer experiments with TP214 were negative for ST in the infant mouse test, giving an average gut/body weight 


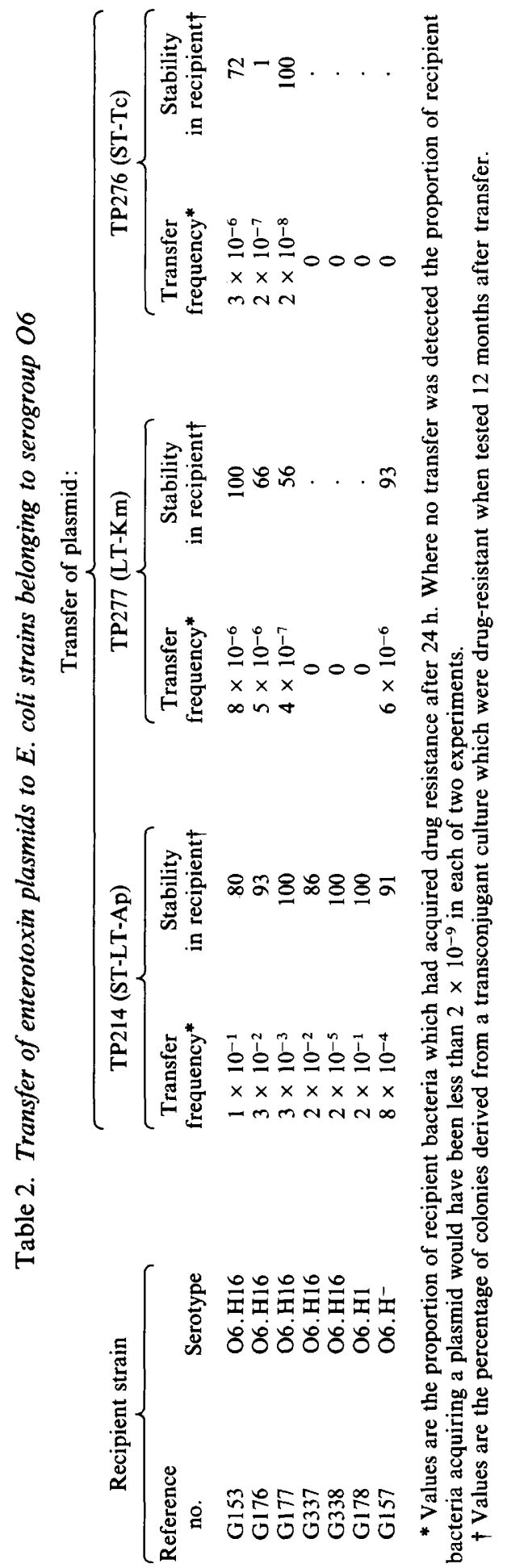



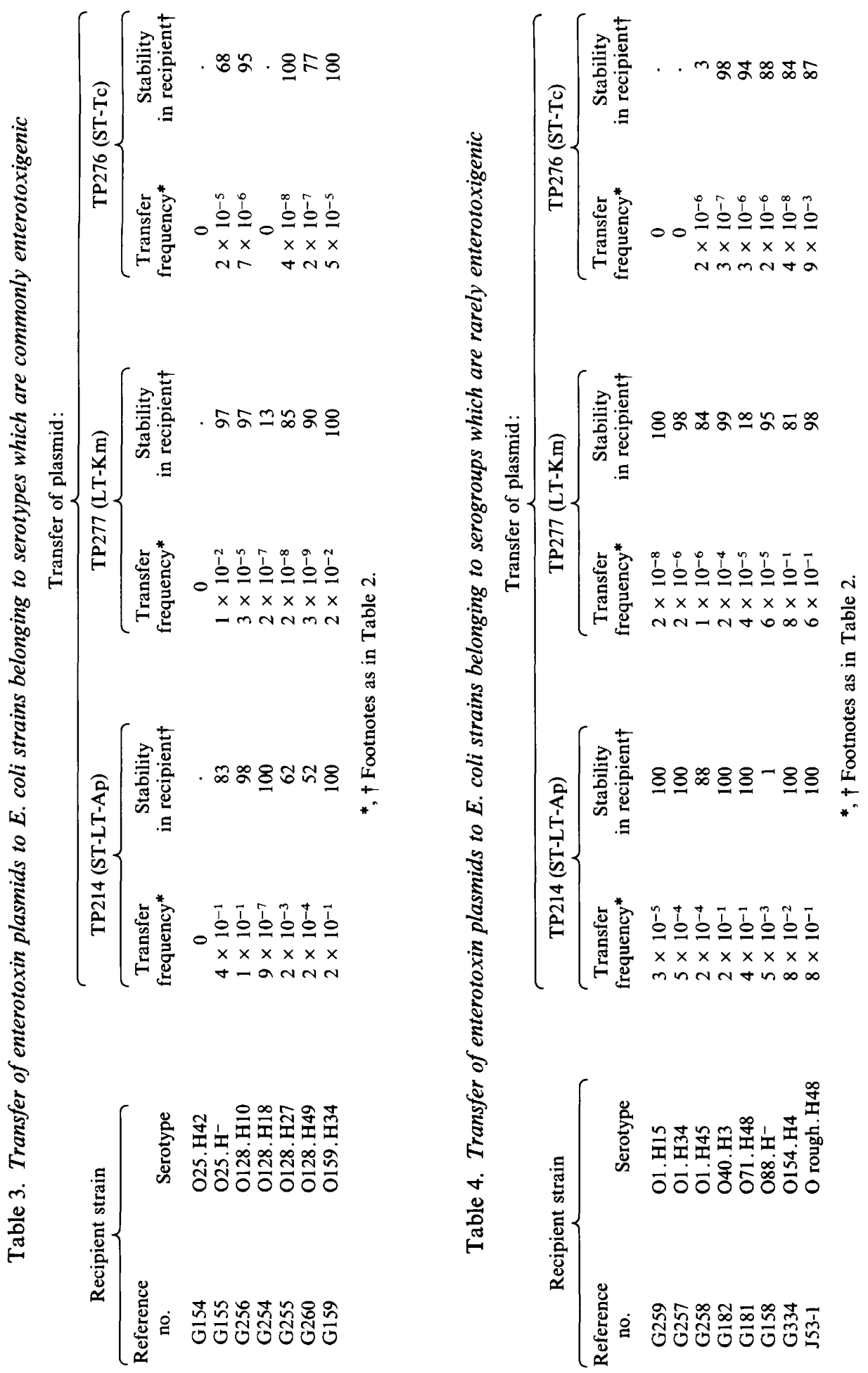
ratio of 0.068 ; all ten transconjugants gave a positive result for LT. Five tetracycline-resistant transconjugants of G158 from each of two separate transfer experiments with TP276 were negative for ST and gave an average gut/body weight ratio in the infant mouse test of 0.073.

An ampicillin-resistant, $\mathrm{LT}^{+}$transconjugant of G158 (G206) transferred ampicillin resistance to $E$. coli $\mathrm{K} 12$ substrain 10R151; the proportion of strain 10R151 acquiring ampicillin resistance after $24 \mathrm{~h}$ was $3 \times 10^{-1}$ and all three transconjugants of 10R151 tested produced LT and ST, giving a gut/body weight ratio greater than $0 \cdot 120$. A tetracycline-resistant transconjugant of G158 (G345) transferred tetracycline resistance to strain 10R151 with a frequency of $2.3 \times 10^{-4}$ per recipient after $24 \mathrm{~h}$; all three 10R151 transconjugants tested produced ST, giving a gut/body weight ratio greater than $0 \cdot 110$. So in transfers of both TP214 and TP276, the transconjugants of G158 had acquired a plasmid coding for ST production which they had been unable to express, but which functioned normally after transfer to a strain of $E$. coli K12.

It was noted that loss of TP214 occurred from G206 (see next section) and, as the test for ST is less sensitive than that for LT, it was possible that a culture containing a low proportion of bacteria carrying TP214 might result in a positive LT test and a negative ST test. However, when G206 was grown in trypticase soy broth with ampicillin $\left(50 \mu \mathrm{g} \mathrm{ml}^{-1}\right)$ to allow the growth only of bacteria carrying TP214, ST was still not detected in the culture filtrate (gut/body weight ratio $0 \cdot 068$ ).

To test whether strain G206 was producing ST at a low rate, two separate culture filtrates of G206 grown in trypticase soy broth with ampicillin $\left(50 \mu \mathrm{g} \mathrm{ml}^{-1}\right)$ were concentrated tenfold using an Amicon UM2 filter. The filtrates gave gut/body weight ratios of 0.092 and 0.061 . When culture filtrates of G345 were similarly concentrated tenfold they gave ratios of 0.087 and 0.093 in the infant mouse test. Concentrated preparations of uninoculated trypticase soy broth gave gut/body weight ratios of 0.069 and 0.073 . So ST production by derivatives of G158 was not demonstrated at a level characteristic of $\mathrm{ST}^{+}$strains by concentrating the filtrates.

\section{Stability of enterotoxin plasmids after transfer}

Transconjugants of the wild-type strains of $E$. coli which had acquired Ent plasmids in the preceding transfer experiments were examined at intervals for the loss of these plasmids as recognized by the loss of resistance to the appropriate drug. At 6 months, loss of an Ent plasmid was only detected from 27 of the 53 transconjugants, and so they were re-examined at 12 months. The proportion of bacteria which still possessed drug resistance 12 months after the acquisition of a plasmid is shown in Tables 2-4. At 12 months, loss of a plasmid was detected in 36 of the 53 transconjugants: in 10 of 21 strains carrying TP214, in 15 of 18 strains carrying TP277 and in 11 of 14 strains carrying TP276. All three plasmids exhibited high, intermediate or low stabilities dependent on the strain in which they were resident. There was no correlation between the ability of a strain to accept the plasmid and its ability to maintain the plasmid.

When tested at six months, the Ent plasmid had been lost from at least 95 of 100 colonies tested from three strains: TP214 from G158 (E. coli O88. $\left.\mathrm{H}^{-}\right)$, TP276 from G176 (E. coli O6.H16) and TP276 from G258 (E. coli O1.H45). The stability of the Ent plasmids in these strains was therefore examined after a shorter time. A single antibiotic-resistant colony was isolated from each transconjugant culture and inoculated in nutrient broth. After growth for $24 \mathrm{~h}$, the culture was plated out. All of 100 colonies tested from each culture were still antibiotic resistant, so plasmid loss was not rapid from these three strains.

It was possible that after acquisition of the plasmid the properties of drug resistance and the ability to produce enterotoxins might be lost independently of each other. It was not feasible to test all colonies examined in the stability studies for enterotoxin production. However, colonies obtained from strain G159 (O159. H34) which stably maintained all three Ent plasmids for 12 months showed that ten ampicillin-resistant colonies carrying TP214 were $\mathrm{ST}^{+} \mathrm{LT}^{+}$, ten kanamycin-resistant colonies carrying TP277 were $\mathrm{LT}^{+}$, and ten tetracycline-resistant colonies carrying TP276 were $\mathrm{ST}^{+}$.

When no loss of drug resistance was detected from a transconjugant after 12 months, transfer experiments were performed and it was confirmed that these strains were able to transmit the resident plasmid to the $E$. coli K12 substrain 10R151. This indicated that stability of the drugresistance character was not due to chromosomal integration. 


\section{DISCUSSION}

Only one strain, E. coli $\mathrm{O} 25$. $\mathrm{H} 42$, failed to acquire any of the Ent plasmids used in this study; however, ETEC belonging to this serotype have been reported previously by Cravioto $e t$ al. (1979), Merson et al. (1979) and Ørskov et al. (1976). The other 21 recipient strains all acquired TP214 (ST-LT-Ap). The plasmid was stably maintained in a number of recipient strains including many belonging to serotypes to which ETEC rarely belong, such as $\mathrm{O} 40 . \mathrm{H} 3$ and O71.H48. In our collection of ETEC from human sources which have been isolated in many countries, strains producing ST and LT are more common than strains producing LT or ST only (Cravioto et al., 1979). Other plasmids encoding ST and LT production should be studied to confirm that this class of Ent plasmid is acquired readily by recipient strains. However, $\mathrm{ST}^{+} \mathrm{LT}^{+}$ strains may be more common because they can arise by more than one mechanism. In some, including the strains from which TP214 originated, the ST and LT genes are encoded on a single plasmid (Gyles et al., 1974; Scotland et al., 1979); in other ST $\mathrm{LT}^{+}$strains, for example $E$. coli O78.H12, the genes for ST and LT production are carried on separate plasmids (McConnell et al., 1980, 1981). The proportion of recipient bacteria acquiring TP214 ranged from $8 \times 10^{-1}$ (for $E$. coli $\mathrm{K} 12$ ) to $9 \times 10^{-7}$ (for $E$. coli $\mathrm{O} 128 . \mathrm{H} 18$ ). The stability of TP214 in a recipient was not correlated with the ability of the recipient to acquire it; for example, the stability was high in both $E$. coli $\mathrm{K} 12$ and $E$. coli $\mathrm{O} 128$. H18, but lower in E. coli $\mathrm{O} 25 . \mathrm{H}^{-}$(transfer frequency $4 \times 10^{-1}$ ) and $E$. coli O128.H49 (transfer frequency $2 \times 10^{-4}$ ).

TP277 (LT-Km) was transferred to 18 of the 22 recipient strains and as for TP214 these included strains belonging to serogroups in which enterotoxigenic strains are rarely found. The proportion of recipient bacteria acquiring the plasmid ranged widely from $8 \times 10^{-1}$ (E. coli O154.H4) to $3 \times 10^{-9}$ (E. coli O128.H49) and the stability of TP277 differed in the transconjugants obtained.

There was transfer of TP276 (ST-Tc) to only 14 of the 22 recipients and in all but one experiment (with $E$. coli $\mathrm{K} 12$ ) the proportion of bacteria acquiring the plasmid was less than $5 \times$ $10^{-5}$. Plasmid loss was shown in 11 of the 14 transconjugants. So this particular ST plasmid was neither transferred efficiently nor maintained well by the strains of $E$. coli tested.

Six of seven strains of serogroup O6 accepted TP214 with transfer frequencies greater than 8 $\times 10^{-4}$, whereas none acquired the LT or ST plasmids readily. Most ETEC of serotype O6. H16 have similarly been shown to produce both ST and LT, and the genes encoding these enterotoxins and CFA/II were carried on a single plasmid (Evans \& Evans, 1978; Peneranda et al., 1980; Smith et al., 1983). The stability of Ent plasmids was not the same in all strains of $E$. coli 66. H16. Differences in the stability of toxin production in three strains of $E$. coli $\mathrm{O} 25 . \mathrm{H} 42$ and also in two strains of $E$. coli $\mathrm{O} 25 . \mathrm{H}^{-}$have been reported indicating, as in the present work, that Ent plasmid stability is not related to the serotype of the host strain (Evans et al., 1977b).

Acquisition of Ent plasmids by strains of $E$. coli $\mathrm{O} 128$ resulted in transconjugants unlike ETEC of this serogroup isolated from patients. In several clinical studies, $E$. coli 0128 of different flagellar types have been shown to produce ST only, with the exception of strains of $E$. coli O128. H49 which produced LT only. G254 (O128. H18) was a poor recipient of TP214 (STLT-Ap) or TP277 (LT-Km) and failed to acquire TP276 (ST-Tc). The other strains of serogroup O128 with flagellar antigens 10,27 and 49 all accepted TP214 with a higher frequency than the other two plasmids. Once acquired, TP277 was not highly stable in G260 (O128. H49) nor was TP276 highly stable in G256 (O128.H10). However, the high stability of certain combinations of plasmid and host bacterium, for example TP276 in G255 (O128. H27), might account for the persistence of certain enterotoxigenic strains in vivo.

The failure to acquire a plasmid could be due to a number of factors. The recipient may already carry plasmids which exclude or are incompatible with the plasmid carried by the donor. Such plasmids would confer individual characteristics on a recipient, which would not be associated with serotype. An attempt had been made to select recipients lacking properties which are known to be plasmid-mediated, but even where these properties were absent, the recipients could have carried plasmids coding for other properties. Effects of such plasmids on the three Ent plasmids would differ. Studies with mutants of $E$. coli $\mathrm{K} 12$ by Hoekstra \& Havekes (1979) have demonstrated that cell envelope components, including lipopolysaccharide, are 
important for the functioning of bacteria as recipients in mating experiments, and affect mating pair formation only with certain donors. Antigenic differences in the wild-type strains could therefore directly affect the ability of a strain to act as a recipient.

This survey of recipient strains shows that many serotypes can express ST and LT. However, although the strain of serotype $\mathrm{O} 88 . \mathrm{H}^{-}$expressed $\mathrm{LT}$, it failed to express ST genes carried on two different plasmids. The only enterotoxigenic $E$. coli $\mathrm{O} 88$ strain in our culture collection produces LT only, but a strain of $E$. coli $\mathrm{O} 88 . \mathrm{H}^{-}$producing ST and LT has been reported by Evans et al. $(1977 b)$. It is not known whether the production of ST and LT was quantitatively similar in the remaining toxigenic transconjugants. There may be wild-type $E$. coli strains which are apparently non-enterotoxigenic but which carry enterotoxin plasmids which can be transmitted to other strains. The use of DNA probes (Moseley et al., 1980) which reveal the presence of the enterotoxin genes, without the necessity of their expression, would be of value in detecting the occurrence of such strains.

In this study, many serotypes of $E$. coli were able to accept and maintain enterotoxin plasmids, and were able to produce enterotoxins in vitro. These included both serotypes to which ETEC commonly belong in diarrhoeal disease studies and serotypes which are frequently isolated from healthy persons but to which ETEC rarely belong. The ability to produce enterotoxins in vitro is however probably insufficient to allow a strain to cause diarrhoeal disease, and other properties, such as the ability to colonize the intestinal mucosa, may be necessary. Thus it is not known whether the enterotoxigenic strains produced in this study would be pathogenic.

The studies of the transfer of pathogenic properties in the laboratory may not resemble the transfer of these properties in vivo but, with this limitation, we conclude that the prevalence of certain serotypes of ETEC is not due to the particular ability of these strains to acquire or maintain Ent plasmids.

\section{REFERENCES}

Anderson, E. S. \& Threlfall, E. J. (1974). The characterisation of plasmids in the enterobacteria. Journal of Hygiene 72, 471-487.

Back, E., Mollby, R. \& KaiJser, B. (1980). Relative importance, seasonal variation, $\mathrm{O}$ - and $\mathrm{K}$-antigens of enterotoxigenic Escherichia coli: a three-and-ahalf year review in Sweden. Journal of Infection 2, 302-315.

Cravioto, A., Gross, R. J., Scotland, S. M. \& Rowe, B. (1979). Mannose-resistant haemagglutination of human erythrocytes by strains of Escherichia coli from extraintestinal sources: lack of correlation with colonisation factor antigen (CFA/I). FEMS Microbiology Letters 6, 41-44.

Deboy, J. M., Wachsmuth, I. K. \& Davis, B. R. (1980). Serotypes of enterotoxigenic Escherichia coli isolated in the United States. Infection and Immunity 29, 361-368.

Evans, D. G. \& Evans, D. J. (1978). New surfaceassociated heat-labile colonization factor antigen (CFA/II) produced by enterotoxigenic Escherichia coli of serogroups $\mathrm{O} 6$ and $\mathrm{O} 8$. Infection and Immunity 21, 638-647.

Evans, D. G., Silver, R. P., Evans, D. J., Chase, D. G. \& Gorbach, S. L. (1975). Plasmid-controlled colonization factor associated with virulence in Escherichia coli enterotoxigenic for humans. Infection and Immunity 12, 656-667.

Evans, D. G., Evans, D. J. \& Tuoa, W. (1977a). Hemagglutination of human group A erythrocytes by enterotoxigenic Escherichia coli isolated from adults with diarrhea: correlation with colonization factor. Infection and Immunity 18, 330-337.
Evans, D. J., Evans, D. G., Dupont, H. L., Ørskov, F. \& ØRSKOV, I. $(1977 b)$. Patterns of loss of enterotoxigenicity by Escherichia coli isolated from adults with diarrhea: suggestive evidence for an interrelationship with serotype. Infection and Immunity 17, 105-111.

Foster, T. J., Howe, T. G. B. \& Richmond, K. M. V. (1975). Translocation of the tetracycline resistance determinant from R100-1 to the Escherichia coli chromosome. Journal of Bacteriology 124, 1153-1158.

FredericQ, P. (1957). Colicins. Annual Review of Microbiology 11, 7-22.

Gross, R. J., Scotland, S. M. \& Rowe, B. (1976). Enterotoxin testing of Escherichia coli causing epidemic infantile enteritis in the U.K. Lancet i, 629631.

Gyles, C., So, M. \& Falkow, S. (1974). The enterotoxin plasmids of Escherichia coli. Journal of Infectious Diseases 130, 40-49.

Hoekstra, W. P. M. \& Havekes, A. M. (1979). On the role of the recipient cell during conjugation in Escherichia coli. Antonie van Leeuwenhoek 45, 1318.

Klipstein, F. A., Rowe, B., Engert, R. F., Short, H. B. \& GROSs, R. J. (1978). Enterotoxigenicity of enteropathogenic serotypes of Escherichia coli isolated from infants with epidemic diarrhea. Infection and Immunity 21, 171-178.

McConnell, M. M., Willshaw, G. A., SMith, H. R., Scotland, S. M. \& Rowe, B. (1979). Transposition of ampicillin resistance to an enterotoxin plasmid in an Escherichia coli strain of human origin. Journal of Bacteriology 139, 346-355. 
McConnell, M. M., Smith, H. R., Willshaw, G. A., Scotland, S. M. \& Rowe, B. (1980). Plasmids coding for heat-labile enterotoxin production isolated from Escherichia coli 078: comparison of properties. Journal of Bacteriology 143, 158-167.

McConnell, M. M., SMith, H. R., Willshaw, G. A., FIELD, A. M. \& Rowe, B. (1981). Plasmids coding for colonization factor antigen I and heat-stable enterotoxin production isolated from enterotoxigenic Escherichia coli: comparison of their properties. Infection and Immunity 32, 927-936.

Merson, M. H., ØRSKOv, F., ØRSKOV, I., SACK, R. B., HUQ, I. \& KOSTER, F. T. (1979). Relationship between enterotoxin production and serotype in enterotoxigenic Escherichia coli. Infection and Immunity 23, 325-329.

Merson, M. H., Rowe, B., Black, R. E., HuQ, I., Gross, R. J. \& Eusof, A. (1980). Use of antisera for identification of enterotoxigenic Escherichia coli. Lancet ii, 222-224.

Moseley, S. L., HuQ, I., Alim, A. R. M. A., So, M., Samadpour-Motalebi, M. \& Falkow, S. (1980). Detection of enterotoxigenic Escherichia coli by DNA colony hybridization. Journal of Infectious Diseases 142, 892-898.

ØRSKOV, I. \& ØRSKOV, F. (1977). Special O:K :H serotypes among enterotoxigenic $E$. coli strains from diarrhea in adults and children. Occurrence of the $\mathrm{CF}$ (colonization factor) antigen and of hemagglutinating abilities. Medical Microbiology and Immunology 163, 99-110.

ØRSKOV, F., ØRSKov, I., Evans, D. J., SACK, R. B., SACK, D. A. \& Wadstrom, T. (1976). Special Escherichia coli serotypes among enterotoxigenic strains from diarrhoea in adults and children. Medical Microbiology and Immunology 162, 73-80.

Peneranda, M. E., ManN, M. B., Evans, D. G. \& Evans, D. J. (1980). Transfer of an ST :LT : CFA/II plasmid into Escherichia coli K12 strain RR1 by cotransformation with PSC301 plasmid DNA. FEMS Microbiology Letters 8, 251-254.

Reis, M. H. L., Matos, D. P., De Castro, A. F. P., Toledo, M. R. F. \& Trabulsi, L. R. (1980). Relationship among enterotoxigenic phenotypes, serotypes and sources of strains in enterotoxigenic Escherichia coli. Infection and Immunity 28, 24-27.

Rowe, B. (1973). The role of Escherichia coli in the diarrhoea of adults. 6th International Symposium of the World Association of Veterinary Food Hygienists. Elsinore.

Scotland, S. M., Gross, R. J. \& Rowe, B. (1977). Serotype-related enterotoxigenicity in Escherichia coli O6. H16 and O148.H28. Journal of Hygiene 79, 395-403.

Scotland, S. M., Gross, R. J., Cheasty, T. \& Rowe, B. (1979). The occurrence of plasmids carrying genes for both enterotoxin production and drug resistance in Escherichia coli of human origin. Journal of Hygiene 83, 531-538.

Scotland, S. M., Day, N. P., Cravioto, A., Thomas, L. V. \& Rowe, B. (1981). Production of heat-labile or heat-stable enterotoxins by strains of Escherichia coli belonging to serogroups O44, O114 and O128. Infection and Immunity 31, 500-503.

Smith, H. R., Scotland, S. M. \& Rowe, B. (1983). Plasmids coding for production of colonization factor antigen II and enterotoxin production in strains of Escherichia coli. Infection and Immunity 40, $1236-1239$

SMYth, C. J., KaIJSER, B., Back, E., Faris, A., Mollby, R., Soderlind, O., Stintzing, G. \& WADSTROM, T. (1979). Occurrence of adhesins causing mannose-resistant haemagglutination of bovine erythrocytes in enterotoxigenic Escherichia coli. FEMS Microbiology Letters 5, 85-90.

TAYLOR, J. (1961). Host specificity and enteropathogenicity of Escherichia coli. Journal of Applied Bacteriology 24, 316-325. 